\title{
A comparison of the Monospot with the Paul-Bunnell test in infectious mononucleosis and other diseases
}

\author{
B. SEITANIDIS
}

\author{
From the Haematology Department, Royal Postgraduate Medical School, London
}

SYNOPSIS The Monospot is a spot test designed for the diagnosis of infectious mononucleosis and its efficacy has been compared with that of the standard Paul-Bunnell test. Three out of $210(1 \cdot 4 \%)$ sera from normal persons and persons suffering from diseases other than infectious mononucleosis gave 'false' positive results when compared with the Paul-Bunnell test. Using 38 sera from patients with strong clinical and haematological evidence of infectious mononucleosis no false negative results were found with the Monospot test. The sera of 37 patients gave positive results with the Paul-Bunnell test: the one negative result was positive using serum taken a few days later.

Sheep red cells have been widely used as an aid to the diagnosis of infectious mononucleosis ever since the description of heterophile antibodies by Paul and Bunnell in 1932. However, sheep red cells are by no means the only animal cells that will react with these antibodies. It has been shown, for instance, that horse, goat, and ox red cells are also agglutinated by the same antibody.

In 1964 Wilkinson and Carmichael demonstrated that in the course of infectious mononucleosis the agglutinin titres in the serum were higher with horse red cells than with sheep red cells. The same observation had been made 28 years earlier by Beer (1936). Lee, Davidsohn, and Slaby published further work on horse red cell agglutinins in 1968. They confirmed the findings of Wilkinson and Carmichael (1964) but they showed that there was considerable overlap in the agglutinin titre against horse red cells when the reactions of sera from patients suffering from infectious mononucleosis were compared with the reactions of sera from normal people. However, if absorptions with guinea-pig kidney and ox red cells were done the expected results were obtained, $i e$, only the ox red cells removed the antibody against horse red cells from the serum of patients suffering from infectious mononucleosis, while both absorbants removed the antibody from the serum of patients suffering from other diseases. Thus the two groups of sera could be clearly differentiated. The horse red cells, moreover, being more sensitive, would detect antibody earlier in the disease than sheep red cells.

With the observation that citrated red cells remain usable for many months it became unnecessary to treat the cells with formalin, and in 1968 Lee, Davidsohn, and Panczyszyn introduced a spot test for the diagnosis of infectious mononucleosis. This test uses citrated horse red cells for the final agglutination and a very fine suspension of guinea-pig kidney and ox red cells for the preliminary absorptions. The absorption suspensions are so fine that they do not obscure the agglutination and the patient's serum can be absorbed and then tested without centrifugation.

The test is available commercially and is called the Monospot test. This investigation was designed to assess the sensitivity and specificity of this test.

\section{MATERIALS}

SERA FROM PATIENTS KNOWN TO BE SUFFERING FROM INFECTIOUS MONONUCLEOSIS The diagnosis had been made on clinical and haematological criteria and was confirmed by a positive result with the conventional Paul-Bunnell test. The unabsorbed serum agglutinated sheep red cells to titres of 40 to 1,280 and the expected results were obtained after absorption.

SERA FROM NORMAL PEOPLE Sera from 100 normal people were used. They were mainly taken from members of the hospital staff, and also from blood donors.

SERA FROM PATIENTS WITH OTHER DISEASES Sera from 321 
60 patients suffering from diseases known to be associated with abnormal antibody production were used. Table I gives the individual diseases. Sera from $\mathbf{5 0}$ children with cervical adenitis but without atypical lymphocytes and with a negative Paul-Bunnell reaction were also used.

\section{TABLE I}

\section{PATIENTS WITH OTHER DISEASES}

Disease Tested with Monospot No. of Patients

Systemic lupus erythymatosus

Lymphosarcoma with high anti-i titre

Autoimmune haemolytic anaemia of the warm antibody type

Cold haemagglutinin disease due to:

(a) Mycoplasma pneumoniae infection

(b) Chronic cold haemagglutinin disease

Myeloma IgG(K)

Hodgkin's disease

Lymphosarcoma

Reticulum cell sarcoma

Chronic myeloid leukaemia

Chronic lymphatic leukaemia

Serum hepatitis

Total

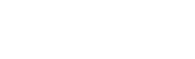

METHOD OF TESTING

THE MONOSPOT TEST The reagents were used exactly as instructed. It is particularly important not to move the slide during the test otherwise agglutination may occur both with the serum absorbed with guinea-pig kidney and the serum absorbed with ox cells, rendering the test unreadable. This may be due to detaching the antibody against horse cells from the absorbants.

THE PAUL-BUNNELL TEST This was done by a standard technique (Dacie and Lewis, 1963).

\section{RESULTS}

PATIENTS SUFFERING FROM INFECTIOUS MONONUCLEOSIS The results of testing 38 infectious mononucleosis sera are shown in Table II. All the sera gave positive results within one minute using the Monospot test.

NORMAL CONTROLS The results of testing sera from normal people or from patients with diseases other than infectious mononucleosis are shown in Table III. The serum from one of the normal people gave a clearly positive result with the Monospot test after 40 seconds. A second person gave a doubtful result at 60 seconds. Both these sera were from members of the hospital staff. In the first case there was a history of acute febrile upper respiratory infection three weeks before complicated by sinusitis. At the time the blood was taken the blood picture showed 9,000 white blood cells per $\mathrm{cmm}$ with $82 \%$ neutrophils. No lymph nodes were palpable at any stage of the disease but it is difficult to rule
TABLE II

SERA FROM KNOWN CASES OF INFECTIOUS MONONUCLEOSIS

\begin{tabular}{lll} 
Case & Time & $\begin{array}{l}\text { Sheep Cell } \\
\text { Agglutinins to } \\
\text { No. }\end{array}$ \\
\hline
\end{tabular}

\begin{tabular}{|c|c|c|c|}
\hline 1 & $+\mathrm{ve}$ & 5 & 320 \\
\hline 2 & +ve & 3 & 640 \\
\hline 3 & +ve & 3 & 1,280 \\
\hline 4 & +ve & 5 & 320 \\
\hline 5 & $+\mathrm{ve}$ & 10 & 320 \\
\hline 6 & + ve & 10 & 160 \\
\hline 7 & + ve & 5 & 640 \\
\hline 8 & $+\mathrm{ve}$ & 40 & 80 \\
\hline 9 & + ve & 3 & 1,280 \\
\hline 10 & $+\mathbf{v e}$ & 3 & 320 \\
\hline 11 & + ve & 5 & 320 \\
\hline 12 & + ve & 30 & 80 \\
\hline 13 & $+\mathrm{ve}$ & 20 & 320 \\
\hline 14 & +ve & 10 & 320 \\
\hline 15 & + ve & 30 & 160 \\
\hline 16 & $+\mathrm{ve}$ & 10 & 640 \\
\hline 17 & +ve & 20 & 320 \\
\hline 18 & $+\mathrm{ve}$ & 40 & 40 \\
\hline 19 & $+\mathrm{ve}$ & 30 & 160 \\
\hline 20 & $+\mathrm{ve}$ & 30 & 80 \\
\hline 21 & $+\mathrm{ve}$ & 10 & 160 \\
\hline 22 & $+v e$ & 3 & 640 \\
\hline 23 & + ve & 5 & 640 \\
\hline 24 & $+\mathrm{ve}$ & 5 & 320 \\
\hline 25 & + ve & 5 & 320 \\
\hline 26 & + ve & 5 & 1,280 \\
\hline 27 & + ve & 20 & 320 \\
\hline 28 & $+v e$ & 5 & 160 \\
\hline 29 & + ve & 5 & 320 \\
\hline 30 & + ve & 5 & 1,280 \\
\hline 31 & $+\mathbf{v e}$ & 10 & 320 \\
\hline 32 & + ve & 5 & 320 \\
\hline 33 & + ve & 3 & 320 \\
\hline 34 & + ve & 3 & 640 \\
\hline 35 & t ve & 3 & 320 \\
\hline 36 & + ve & 3 & 320 \\
\hline 37 & +ve & 5 & 320 \\
\hline 38 & +ve & 3 & 640 \\
\hline
\end{tabular}

TABLE III

KNOWN NON-INFECTIOUS MONONUCLEOSIS SERA

\begin{tabular}{llllll} 
& $\begin{array}{c}\text { No. of } \\
\text { Cases }\end{array}$ & Positive & Doubtful & Negative \\
\hline Normal controls & 100 & 1 & 1 & 98 \\
Various diseases & 110 & 1 & - & 109
\end{tabular}

out infectious mononucleosis entirely. The PaulBunnell test was negative and the subject's serum agglutinated sheep red cells to the following titres: $\sigma$ unabsorbed serum 160, absorbed with guinea-pig $N$ kidney 20 , absorbed with ox cells 20 . In the second case there was no history of illness in the previous six months. The Paul-Bunnell test was again clearly negative and the agglutinin titres were as follows: unabsorbed serum 80 , absorbed with guinea-pig kidney 10 , absorbed with ox cells 10 . Three months later, serum from the first subject again gave a positive result with the Monospot test and a negative with the Paul-Bunnell test. Serum from the second subject gave a negative result with both tests when the test was repeated three months later. 
PATIENTS WITH OTHER DISEASES One serum from a patient suffering from serum hepatitis gave a positive result with the Monospot test within 20 seconds. The Paul-Bunnell test was negative and agglutinated sheep red cells to the following titres: unabsorbed serum 320, absorbed with guinea-pig kidney 40, absorbed with ox cells 80 (Table III).

\section{DISCUSSION}

A firm diagnosis of infectious mononucleosis still requires the detection of specific heterophile antibodies in addition to the clinical and haemotological findings associated with this disease. The Monospot test for the detection of these antibodies has the advantages of simplicity and speed. It can be done by staff with very little training provided the instructions are followed exactly. It gave clear-cut positive results in all those patients who were known to have a positive Paul-Bunnell test, including one patient whose serum gave, initially, a negative test. The serum from this patient, who had strong clinical and haematological evidence of infectious mononucleosis, gave a positive Paul-Bunnell test five days later.

Only three out of 210 control sera $(1.4 \%)$ gave 'false' positive results with the Monospot test when compared with the Paul-Bunnell test. No 'false' negative results were obtained. The horse cells still gave satisfactory results after two months' storage.

I would like to thank Dr Sheila Worlledge and Professor J. V. Dacie for their help and advice, and Miss Janet Baines for secretarial help.

\section{REFERENCES}

Beer, P. (1936). J. clin. Invest., 15, 591.

Dacie, J. V., and Lewis, S. M. (1963). Practical Haematology, 3rd ed. Churchill, London.

Lee, C. L., Davidsohn, I., and Slaby, R. (1968). Amer. J. clin. Path., 49, 3.

$-\ldots, \ldots$, and Panczyszyn, O. (1968). Ibid., 49, 12.

Paul, J. R., and Bunnell, W. W. (1932). Amer. J. med. Sci., 183, 90. Wilkinson, P. C., and Carmichael, D. S. (1964). J. Lab. clin. Med., 64, 529. 